\title{
Yuri B. Yurov (1951-2017)
}

\author{
Ivan Y. lourov ${ }^{1,2^{*}}$ and Svetlana G. Vorsanova ${ }^{1,2}$
}

- It will take people ten years to forget!

- It will indeed be honored across two epochs!

\section{Marina I. Tsvetaeva}

On 12 December, 2017, Professor Yuri Borisovich Yurov (Fig. 1) passed away peacefully at the Federal Scientific Clinical Center for Resuscitation and Rehabilitation, a renowned resuscitation/rehabilitation institute located not far from Moscow. The tragic, albeit inevitable, ending of Yuri's courageous fight against a devastating cancer has suddenly stricken all his colleagues and friends. Our deepest sorrow has paralyzed our capacity to do anything, leading us to recognize the vital need for reevaluating Yuri's scientific and personal legacy.

Yuri's life is an example of unselfish devotion to bioscience. His contribution to genetics and practical medicine is hard to estimate. It is truly immense! Since Yuri's personality can be defined using such epithets as "bright intelligence", "overwhelming kindness", and, especially, "extreme modesty", it is not surprising that he was always skeptical about "aggressive public relations efforts" to advance careers and theories, which are so popular in modern biomedicine. Thus, one should not be surprised about the lack of annoyingly large lists of his awards, honors, commitments, etc. Certainly, Yuri's research was awarded local and international prizes and grants from time to time. These, however, are a poor reward for his tremendous endeavors to organize, undertake, and present such a groundbreaking body of work. To redress this historical injustice, we decided to describe Yuri's life in a biographical review instead of a traditional obituary limited to a short rueful notification. We do hope that our effort to share the experience of being alongside this brilliant researcher and bright person gives a succinct

\footnotetext{
* Correspondence: ivan.iourov@gmail.com

${ }^{1}$ Laboratory of Molecular Genetics and Cytogenomics of the Brain, Mental Health Research Center, Zagorodnoe shosse 2/16, 117152 Moscow, Russia ${ }^{2}$ Veltischev Research and Clinical Institute for Pediatrics of the Pirogov Russian National Research Medical University, Ministry of Health of Russian Federation, Moscow 125412, Russia
}

understanding of Yuri's profound, albeit non-explicit, impact on biomedicine and neuroscience.

Yuri was born on 11 December, 1951, in Zhukovsky, a city near Moscow known as a home to several major research institutes involved in designing aircraft, to a family of an engineer-researcher. While graduating from school, he chose biology as a field of further higher education. Today, we know that it was a good choice. His admission to the Faculty of Biology at Lomonosov Moscow State University was associated with a story that picturesquely exposes the essence of Yuri's personality. The initial results of the matriculation examination did not allow his admission to the biological faculty of Lomonosov Moscow State University, but still allowed him to enter the Faculty of Biology at Moscow State Pedagogical Institute. Later on, he unintentionally told his father that he is " $100 \%$ sure" to pass the matriculation examination at Lomonosov Moscow State University. His father decided to appeal to the university in this regard, which revealed that Yuri was right. As a result, he was admitted to the faculty of biology at Lomonosov Moscow State University. There, he made the ultimate decision to become a researcher in genetics.

In the beginning, Yuri studied DNA replication [1]. Initially, his research was performed at Kurchatov's Institute of Moscow with Dr. Evgenii Ananiev, a recognized Russian geneticist who contributed to the research of mobile genetic elements and plant chromosomes [2, 3]. He pursued the research of DNA replication at Institute of Medical Genetics (Academy of Medical Sciences of the USSR, Moscow) and made appreciable progress thereof [4-10]. In 1977, Yuri defended his Ph.D-thesis "Replicational organization of chromosomal DNA in cultured normal and abnormal cells of humans and animals". However, he was obliged to cease studying DNA replication. As we previously implied, Yuri was completely disinterested in backroom intrigues and local politics. This was not the case for the majority of group leaders and administration representatives at the medical genetics institutes at the end of seventies and beginning of the eighties. Fortunately, psychiatric genetics was a research focus of the All-Union Mental Health Research Center (Academy of Medical Sciences of the USSR, Moscow), where Yuri was invited to develop new 


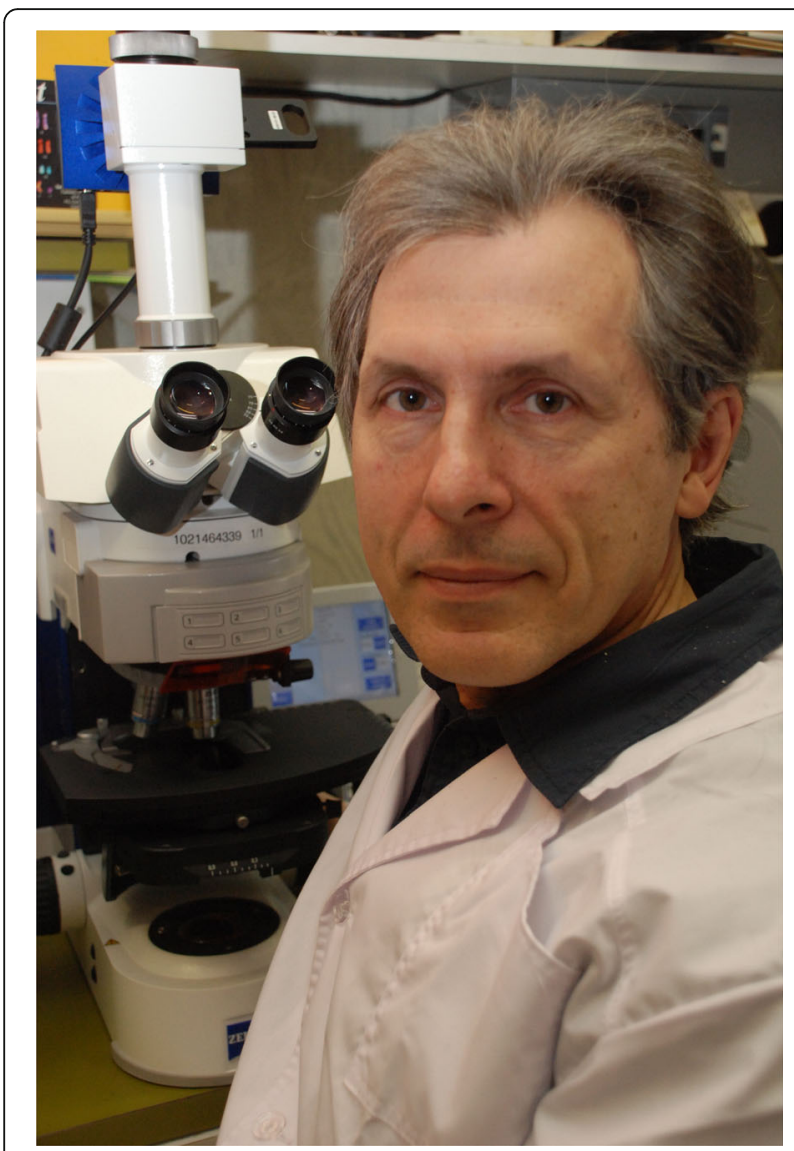

Fig. 1 Yuri B. Yurov (1951-2017)

techniques for studying the human genome at the chromosomal level in brain disorders by Professor Marat E. Vartanian, who had then become the head of this center. Henceforth, his research career would be tightly linked to Mental Health Research Center, where he successfully completed his doctoral dissertation for receiving the degree of Doctor of Science (the highest academic degree achieved through defending a thesis significantly more voluminous than a canonical Ph.D thesis) - "Molecular cytogenetics of heterochromatic regions in the human genome" - and became the head of the Cytogenetics Laboratory (laboratory of cytogenetics and genomics of mental disorders).

So began Yuri's molecular cytogenetic odyssey. He was among the first researchers in the world to develop a technique of in situ hybridization with cloned DNA sequences for the analysis of human chromosomes [11]. Almost immediately, the results of these developments were found applicable for molecular cytogenetic diagnosis of chromosomal abnormalities. Unfortunately, the article describing these applications was published two years later after the submission along with other articles reporting similar results [12]. His molecular cytogenetic studies were based on a part of his immense research activity referred to molecular, cytogenetic and evolutionary analysis of alpha satellite DNA and constitutive heterochromatin [13-19]. Evolutionary molecular (cyto)genetic studies have also underlined long-standing friendship and collaboration with Professor Gérard Roizès (Institut de Biologie, Montpellier, France) [20], with whose team (équipe) he worked for several years. During this period, he had a family tragedy. His stepson - Dr. Ilia V. Soloviev, a prodigious young researcher and a pioneer of molecular cytogenetics and cytogenetic genome research, whose brilliant work and original ideas still form research directions in our labs - tragically passed away. This sorrow led to re-assessing life priorities. More intense research was undertaken to decrease the suffering.

Inspired by the first success of his molecular cytogenetic research and diagnosis [21-25], Yuri together with his closest colleagues undertook further studies to increase the efficiency and scope of molecular cytogenetics. Thus, a series of (ultra) rapid fluorescence in situ hybridization (FISH) protocols was proposed $[26,27]$. One rapid protocol, based on microwave activation [26], was developed $10-15$ years before the introduction of such approaches to diagnostic and research practice. Additionally, FISH-based molecular cytogenetic techniques for the identification of marker chromosomes were proposed [28-30]. At that time, the essential issue of Yuri's research was the creation of an original DNA probe collection [16, 17, 31], which formed a firm basis for almost all our further studies and developments in molecular cytogenetics. For instance, interphase detection of chromosome 21 aneuploidy for prenatal diagnosis was significantly improved [27, 32]. Multicolor interphase FISH with centromeric (chromosome-enumeration) DNA probes was the next major breakthrough of research headed by Yuri [33]. This technique is still very popular and is actually the most direct way to analyze numerical chromosomal changes in large cellular populations at single-cell level. It was also found applicable for studying sperm providing new opportunities for reproductive genetics [34]. These studies can be designated as the main basis for the first generation interphase (molecular) cytogenetics developments allowing the analysis of chromosomal loci or ambiguous/amorphous chromosome territories (chromosomal parts' territories) without an integral view of the whole interphase chromosomes.

Another layer of Yuri's research is represented by studying X-linked diseases [35-37], more precisely, Rett syndrome. The studies of Rett syndrome performed with his participation were global $[38,39]$. These included the confirmation of an X-linked nature of the syndrome [40-42], mutational analysis in Russian Rett syndrome cohorts [43], uncovering pathoepigenetic mechanisms specific for Rett syndrome (i.e. alterations to chromosomal DNA replication, X-linked bi-allelic expression, parent-of-origin-like effects on $\mathrm{X}$ chromosome inactivation) 
[40-42, 44-46], and discovering the microdeletion nature of MECP2-mutation negative Rett syndrome cases [47, 48]. The success of Rett syndrome studies culminated in 2016, when the VIII World Rett Syndrome Congress (scientifically organized with active Yuri's participation) was held in Kazan, Russia. The congress highlighted true success and recognition of Rett syndrome research in Russia, which is, in turn, the result of Yuri's efforts. Regretfully, due to numerous unexpected problems, we have not still published the article describing this congress. Nonetheless, we await this article to be published in Molecular Cytogenetics soon.

Yuri's original collection of DNA probes was found useful in numerous studies performed by our labs and his collaborators all over the world. These studies included, but were not limited to, analyses of chromosomal abnormalities and instability (mosaicism) in a variety of human tissues [49-52], mapping breakpoints of structural chromosome rearrangements [52-55], discovering the role of chromosomal mosaicism (mosaic aneuploidy and polyploidy) in spontaneous abortion [5660]. However, there was a real need to widen the spectrum of molecular cytogenetic techniques, especially for studying interphase chromosomes and genomic (chromosomal) variations at single-cell level in different tissues [61-65]. In this context, it is to mention one of the major theoretical contributions to bioscience made by Yuri.

It has been postulated without any evidence that all cells of an organism possess identical genomes. Taking into account simply the amount of mitoses needed to generate the required amount of cells of an organism, we inevitably come to a conclusion that these postulates are nonsense. Although the scale of mosaicism in somatic tissues is to be determined more thoroughly, one had to admit the existence of overlooked cellular fractions featured by unshared genomes [66]. Regardless of being presented as an encyclopedic knowledge [67], intercellular/ somatic genomic variations were more-or-less recognized as an important mechanism for interindividual diversity in health and disease during the last few years only. Moreover, we had proposed a neurocytogenetic hypothesis suggesting that genetic mechanisms of brain diseases are more likely to be related to cellular populations with abnormal genomes primarily affecting the brain. In other words, Yuri insisted that we should perform genetic analysis of the brain to uncover the mechanisms of central nervous system diseases [68]. As one can guess, the idea encountered serious resistance from skeptical ignorance to aggressive denial. It is rare for a researcher to prefer to break a tradition to the detriment of its "publicability" and funding opportunities. When the overwhelming majority of studies in psychiatric (medical) genetics are made using DNA isolated from blood, it is naïve to think that such ideas may be accepted quietly. Yuri did not care much about it. He preferred creating trends to following trends. Interestingly, this approach to brain diseases is quite popular in the latest neuroscience literature, unfortunately often without appropriate references to the original theoretical articles.

To succeed in studying somatic genome variations in the brain, new molecular cytogenetic techniques were strongly required. Using positive experience in developing original computer-assisted analysis of FISH results [69], we elaborated a quantitative FISH protocol [70, 71]. The latter was found applicable for analysis of chromosomal heteromorphisms/pericentromeric regions (i.e. identification of parental origins of homologous chromosomes with efficiency comparable to PCR-based methods) [72], distinguishing between interphase chromosome loci pairing or associations and chromosomal loss [73], and determining specific genome architecture within human interphase nuclei [74]. Still, the possibility to see an interphase chromosome in its integrity was not available. To offer the opportunity to see a banded interphase chromosome, we took advantage of a collaboration with Professor Thomas Liehr (Jena, Germany) for developing a new method for analysis of interphase chromosomes in their integrity, entitled interphase chromosome-specific multicolor banding (ICS-MCB) [75-78]. Finally, there was a lack of protocols for obtaining cellular suspensions from postmortem brain specimens applicable for specific FISH-based approaches to single-cell interphase chromosome analysis. The problem was soon solved [79] and became a continuously applicable method for human molecular neurocytogenetics [80]. The results of these interphase cytogenetic achievements were summarized in quite a highly cited (for non-canonical cytogenetics) review [81] and in quite a widely read book [82].

Yuri's idea about the link between pathogenesis of psychiatric, neurodevelopmental, and neurodegenerative diseases and genetic pathology exclusively affecting the central nervous system required the knowledge concerning the background rate of sporadic (chromosomal) mutations in the unaffected brain. Under his leadership with the valuable help of Professor Sergei Kutsev, who provided the unique specimens, we performed analysis of chromosomes in the developing human brain [83-86]. As a result, it had been sensationally reported that the overall percentage of aneuploid cells is $30-35 \%$ in the developing brain indicating aneuploidization and developmental chromosomal instability to be an additional pathological mechanism for neuronal genome diversification at molecular and cellular levels [86]. In the unaffected postnatal brain, these rates are significantly lower [75, 84, 87, 88].Therefore, Yuri's hypothesis was supported at this stage.

Schizophrenia was the first disease considered in the neurocytogenetic context. Actually, it was the first neurocytogenetic analysis in human with the special 
attention to mosaicism confined to the brain showing chromosomal abnormalities/instability causative for mental illness [89]. This is mainly due to the fortunate availability of the Mental Health Research Center collection of postmortem brain specimens managed by Dr. Viktor Vostrikov and Professor Natalia Uranova (Mental Health Research Center, Moscow, Russia). Interestingly, somatic mosaicism, even in a wider sense (i.e. unconfined to a tissue), was not a focus of psychiatric genetics research at all at that time [90]. During the next years, Yuri's neurocytogenetic research of schizophrenia was successful. We were able to demonstrate the disease association with chromosome 1-specific aneuploidy (instability) and to show the involvement of brain-specific low-level post-zygotic aneuploidy in schizophrenia and comorbid psychiatric disorders [91-94].

Neurodegenerative diseases were another focus of Yuri's neurocytogenetic research [87]. First, Alzheimer's disease was found to be associated with aneuploidy confined to the brain. Moreover, it marked the end of debates about parallels between Alzheimer's disease and Down syndrome. Consequently, it was postulated that Alzheimer's disease is associated with chromosome 21-specific aneuploidy and instability in the brain, but it is not a subtype of Down syndrome (trisomy 21 ) $[87,95,96]$. This devastating neurodegenerative disease is likely to result from a complex mechanism involving abortive cell cycle re-entry, replication stress in postmitotic neural cells, genome instability, and deposition of amyloid beta-peptide [97]. Furthermore, additional studies showed a link between cytogenetic markers of aging and Alzheimer's disease pathogenesis [98]. Accordingly, numerous hypotheses about mechanisms for Alzheimer's disease were merged together to form the Alzheimer's disease pathogenetic cascade.

The support, provided by Ataxia Telangiectasia Children's Project, significantly helped Yuri to pursue his neurocytogenetic research of neurodegenerative diseases. Yuri focused on an intriguing paradox of ataxia telangiectasia: exclusive cerebellar neurodegeneration [99]. This neurodegenerative disease was found to exhibit chromosome instability in the brain [87]. In addition, ataxia telangiectasia also demonstrated a link between area- and chromosome-specific instability and neurodegeneration [100]. These findings were then suggested to be a likely basis for the therapeutic interventions in neurodegenerative diseases mediated by chromosome instability [101]. Thus, the first evidence that genome/chromosome instability is able to produce neurodegeneration, whereas it is generally assumed to be associated with cancer, was provided.

Parallelly, somatic (cyto)genomic variations were studied in autism. As a result, it was discovered that somatic mosaicism (aneuploidy) is a genetic risk factor for autism [102]. Furthermore, these studies demonstrated an unprecedentedly high prevalence of chromosomal heteromorphisms in autistic children [103, 104]. So far, these two types of genomic variations seem to be the most common ones in this pervasive neurodevelopmental disorder. Theoretically, these data were applicable for explaining the male-to-female ratio in autism [105]. Furthermore, chromosomal heteromorphisms and instability were then shown to co-segregate with mental illness in autistic pedigrees $[106,107]$. These studies were followed by neurocytogenetic analysis of the autistic brain. We do hope to present the results in the nearest future.

This area of Yuri's research allowed proposing a "global mosaicism pathway" for human intercellular/interindividual diversity and disease pathogenesis throughout the ontogeny [108]. Interestingly, it was associated not only with aneuploidy, but also with structural chromosome abnormalities (i.e. dynamic mosaicism, tissue- (or sub-tissue) specific mosaicism and local tissue-specific increase of chromosome instability [100, 109]. Furthermore, this "global mosaicism pathway" highlighted developmental chromosome instability as a possible cause of cancer in early childhood [110]. Finally, the pathway explained cell senescence and aging of tissues composed of postmitotic cells through the accumulation of somatic (chromosomal) mutations [111]. All these experimental and theoretical analyses underlined the basis of molecular cytogenomics, which aggregated and correlated data on heritable and non-heritable (somatic mosaicism) genomic variations [112]. It is noteworthy that the term "cytogenomics" was suggested by Yuri ten years before it started to be widely used in similar contexts. This enormous body of research culminated in publishing a special issue on somatic genome variations (mosaicism) in Current Genomics [113]. In that issue, Yuri and colleagues provided three main directions of studying somatic genome variations: somatic mosaicism's role in health and disease [114], somatic genome variations in the ontogenetic context [115], and diagnostic issues of studying somatic genome variability [116]. The paradigm of somatic genomics was then repeatedly postulated indicating the global contribution of genome/chromosome instability to brain diseases [117-120]. Finally, somatic genomic theory suggested a new generalized pathway, linking germline/heritable genome variations, somatic mosaicism and genetic-environmental interactions [121]. Yuri's research of somatic genome variations is another example of his major contribution to bioscience. He did succeed to persuade biomedical researchers that genomes of somatic cells are not identical. So, the human is not a parody of a huge unicellular organism anymore.

Summarizing the developments in single-cell biology and data on somatic mosaicism, we immediately found that systems biology approaches are required for a successful molecular diagnosis and research dedicated to medical genetics and somatic genomics [122]. We started to use original systems biology or bioinformatics approaches to prioritize autism/intellectual disability genes by simple 
protocols [123]. However, more sophisticated approaches specially elaborated for molecular cytogenetics were soon found to be required. As a result, a new dimension (in silico dimension) in molecular cytogenetics was discovered [124]. In silico molecular cytogenetics was shown to uncover molecular and cellular mechanisms of diseases associated with chromosomal imbalances and copy number variations. Additionally, it became a basis for original algorithms of fusion and network-based classification of molecular cytogenetic data [125] as well as proposing global pathways of neuropsychiatric diseases for therapeutic interventions [126]. These algorithms were successfully used for uncovering mechanisms of chromosomal instability and somatic mosaicism [127, 128]. Moreover, in silico approaches to chromosomal imbalances are applicable for developing successful treatments of chromosomal abnormalities, which are considered incurable genetic conditions [129]. To this end, we recently proposed a practical in silico protocol for molecular cytogenetic diagnosis of neuropsychiatric diseases [130]. As one can see, Yuri made a significant input in clinical (genomic) bioinformatics. His efforts in this field resulted in significant quality of life increase (or even healing) of children suffering from presumably hopeless genetic diseases.

Yuri's contribution to practical medicine or more precisely molecular diagnosis was immense. His diagnostic research was intimately related to working at laboratory of molecular cytogenetics of neuropsychiatric diseases at Veltischev Research and Clinical Institute for Pediatrics of the Pirogov Russian National Research Medical University (Institute of Pediatrics and Pediatric Surgery), Moscow, Russia. Since the late eighties, numerous reports were published about the increase of diagnostic efficiency of molecular cytogenetic techniques [21, 24, 25, 28, 49-51, 102-107, 112, 116, 117, 130, 131]. For instance, the first Russian array CGH (comparative genomic hybridization) study of a clinical population was the result of Yuri's tremendous efforts [131, 132]. His diagnostic research was not limited to chromosome abnormalities and copy number variations. Under Yuri's supervision, an approach to molecular diagnosis of epigenetic diseases was proposed [133]. This led to a discovery of a new epigenomic mechanism of neurodevelopmental diseases in childhood [134]. His approaches to molecular diagnosis of structural genomic variations in autism and intellectual disability including uncovering mechanisms and possible therapies were recently found highly effective [135]. Finally, it is important to mention that Yuri's efforts resulted in elevating the educational level in the field of molecular genetic diagnosis. Our laboratories receive consistent thanks of almost all Russian-spoken specialists from all over the world because of his co-authored books [136-142], which are the only books describing real cytogenetics, molecular cytogenetics and cytogenomics in Russian.
The latest results of Yuri's research formed a firm basis for molecular cytogenetics earning its well-deserved place in postgenomic biomedicine. These efforts resulted in a special issue of Current Genomics, which uncovers new realities and dimensions of molecular cytogenetics cytogenomics or molecular cyto(post)genomics [143]. In this issue, Yuri and his colleagues reported a part of aneuploidy research in the schizophrenia brain and comorbid psychiatric disorders [94]. Additionally, our original bioinformatic techniques were shown to be truly applicable for basic and applied cytogenomics to uncover molecular, cellular, physiological and even neuropsychological mechanisms of diseases caused by chromosome imbalances [144]. Furthermore, we proposed an original cytogenomic hypothesis suggesting that human behavior might be regulated through changes in proportions of somatic mosaicism levels resulted from complex interaction between mutational burden and environment [145]. Unfortunately, the issue was published at that time, when Yuri was unable to see it (posthumously), even though its content was prepared in 2016-2017.

A very special part of Yuri's research life was Molecular Cytogenetics, the journal founded in 2008 with his essential participation [146]. It all started as a joke. In 2005, during a conversation with our good friend and colleague Professor Thomas Liehr, somebody said that it is always challenging for a group of independent scientists (i.e. researchers uninvolved in large sophisticated collaborative webs and hierarchical relationships) to publish an article containing bold ideas, unique, albeit logic and scientific, views, and own conclusions in their original form, especially in the field of cytogenetics. Jokingly, it was said that there is an easy solution to this problem: one just had to establish a new journal dedicated to chromosome biology and molecular cytogenetics based on a principle, something like "good music for good people" with the only exception of being a scientific journal. It is well-known that "there is a grain of truth in every joke". It was a solution, but not an easy one. It took three years to begin the journal. Yuri became one of the Editors-in-Chief as one of the founders. From that time onwards it took then five years to receive the first official impact factor [147]. Further success was achieved when the journal was ranked first out of all journals specifically dedicated to cytogenetics. The editorship of Molecular Cytogenetics was Yuri's honorable duty. We are only starting to understand the extent of his contribution to the journal's success.

Yuri left endless amount of unfinished works, numerous descriptions of his original ideas and theories, and tens of thousands of paper sheets containing data. Consequently, it is now our duty to finalize the studies and to publish the results of his enormous research activity. We do hope that these publications will appear in the nearest future. 
It is not a secret that Yuri's family is the core of team members of three laboratories which have performed such a great body of biomedical research. He is a grandfather of three granddaughters, who remember him as the kindest and nicest person in the world. Thus, this is also a grievous personal loss for us, his family.

We miss him a lot! The gap in our life resulted from this untimely and unacceptable loss cannot be filled. We would like to express our thanks to all the friends and colleagues for their kind support. The only thing we can do now is to multiply and to share the legacy of such an outstanding researcher as Professor Yuri B. Yurov.

\section{Authors' contributions}

IYI drafted the manuscript. SGV provided information. Both authors read and approved the final manuscript

\section{Competing interests}

The authors declare that they have no competing interests.

\section{Publisher's Note}

Springer Nature remains neutral with regard to jurisdictional claims in published maps and institutional affiliations.

\section{Received: 18 April 2018 Accepted: 14 May 2018}

Published online: 13 June 2018

\section{References}

1. Iurov IB. DNA replication in a primary culture of human hepatocytes. Dokl Akad Nauk SSSR. 1976;229(2):472-5.

2. Anan'ev EV, lurov IB, Polukarova LG. Rate of DNA synthesis and the size of replication units in cell culture of Drosophila melanogaster. Mol Biol (Mosk). 1976;10(5):987-97.

3. Ananiev EV, Polukarova LG, Yurov YB. Replication of chromosomal DNA in diploid Drosophila melanogaster cells cultured in vitro. Chromosoma. 1977; 59:259-72.

4. Yurov YB. DNA replication in human diploid cells of different origin. Cell Differ. 1977;6:95-104

5. Iurov IB. Replication of chromosomal DNA in Chinese hamster cells, cultivated at different temperatures. Tsitologiia. 1977;19(9):1064-7.

6. Yurov YB. Replication of chromosomal DNA in cultured abnormal human cells. Hum Genet. 1978;43:47-52.

7. Yurov YB. The rate of fork movement during DNA replication in mammalian cells. Chromosoma. 1979;74:347-53.

8. Yurov YB. Do clusters of replication units in the mammalian cells exist? Exp Cell Res. 1979:123:369-74.

9. Yurov YB. Rate of DNA replication fork movement within a single mammalian cell. J Mol Biol. 1980;136:339-42.

10. Iurov IB, Vorsanova SG. DNA replication in cultured amniotic fluid cells. Biull Eksp Biol Med. 1981:92(9):349-52.

11. lurov IB. Optimization of the conditions for the in situ hybridization of cloned DNA sequences and for the differential staining of human chromosomes. Biull Eksp Biol Med. 1984;97(5):595-8.

12. Vorsanova SG, Yurov YB, Alexandrov IA, Demidova IA, Mitkevich SP, Tirskaia AF. 18p- syndrome: an unusual case and diagnosis by in situ hybridization with chromosome 18-specific alphoid DNA sequence. Hum Genet. 1986;72: 185-7.

13. Yurov YB, Mitkevich SP, Alexandrov IA. Application of cloned satellite DNA sequences to molecular-cytogenetic analysis of constitutive heterochromatin heteromorphisms in man. Hum Genet. 1987;76:157-64.

14. Iurov IB, Mitkevich SP, Aleksandrov IA. Molecular cytogenetic research on the polymorphism of segments of the constitutive heterochromatin in human chromosomes. Genetika. 1988;24(2):356-65.

15. Alexandrov IA, Medvedev LI, Mashkova TD, Kisselev LL, Romanova LY, Yurov YB. Definition of a new alpha satellite suprachromosomal family characterized by monomeric organization. Nucleic Acids Res. 1993;21:2209-15.
16. Yurov YB, Laurent AM, Marcais B, Vorsanova SG, Roizes G. Analysis of pericentromeric chromosome 21 specific YAC clones by FISH: identification of new markers for molecular-cytogenetic application. Hum Genet. 1995:95:287-92.

17. Solov'ev IV, lurov IB, Vorsanova SG, Marcais B, Rogaev El, Kapanadze BI, Brodianskii VM, lankovskii NK, Roizes G. Study of alpha-satellite DNA in cosmid libraries, specific for chromosomes 13, 21, and 22, using fluorescence in situ hybridization. Genetika. 1998;34(11):1470-9.

18. Marzais B, Vorsanova SG, Roizes $G$, Yurov YB. Analysis of alphoid DNA variation and kinetochore size in human chromosome 21: evidence against pathological significance of alphoid satellite DNA diminutions. Tsitol Genet. 1999;33(1):25-31.

19. Vorsanova SG, Yurov YB, Brusquant D, Carles E, Roizes G. Two new cases of the Christchurch (Ch1) chromosome 21: evidence for clinical consequences of de novo deletion 21P. Tsitol Genet. 2002:36(1):46-9.

20. Roizes $G$, Marcais B, Yurov Y. Les centromères des chromosomes de mammifères. Med Sci. 1994:10(3):282-95.

21. Vorsanova SG, lurov IB, Aleksandrov IA, Demidova IA, Mitkevich SP. Molecular-cytogenetic diagnosis of hereditary diseases associated with diverse anomalies of $X$ chromosome. Pediatriia. 1989;1:76-80.

22. Vorsanova SG, Yurov YB, Kurbatov MB, Kazantzeva LZ. Translocation t(1;17)(q12; q25) with a clinical picture like of a proximal deletion of 1q: identification by in situ hybridization with chromosome 1-specific satellite DNA probes. Hum Genet. 1990;86:173-4.

23. Iurov IB, Selivanova EA, Deriagin GV. Human alpha-satellite DNA specific to chromosomes 13 and 21: use for the analysis of polymorphism of acrocentric chromosomes and the origin of the additional chromosome 21 in Down's syndrome. Genetika. 1991;27(9):1637-47.

24. Vorsanova SG, lurov IB, Deriagin GV, Solov'ev IV, Bytenskaia GA. Method of diagnosing aneuploidies using in situ hybridization: analysis of interphase nuclei. Biull Eksp Biol Med. 1991;112(10):413-5.

25. Vorsanova SG, lurov IB, Demidova IA, Vekhova NV. Chromosomal anomalies in children with undifferentiated forms of mental retardation based on molecular cytogenetic research data. Tsitol Genet. 1993;27(3):72-8,

26. Soloviev IV, Yurov YB, Vorsanova SG, Malet P. Microwave activation of fluorescence in situ hybridization: A novel method for rapid chromosome detection and analysis. Focus. 1995;16:101-2.

27. Soloviev IV, Yurov YD, Vorsanova SG, Malet P, Zerova TE, Buzhievskaya TI. Double color in situ hybridization of alpha-satellite chromosome 13, 21 specific cosmid clones for a rapid screening of their specificity. Tsitol Genet. 1998;32(4):60-4.

28. Vorsanova SG, Yurov YB, Soloviev IV, Demidova IA, Malet P. Rapid identification of marker chromosomes by in situ hybridization under different stringency conditions. Anal Cell Pathol. 1994;7:251-8.

29. Plattner $R$, Heerema NA, Yurov YB, Palmer CG. Efficient identification of marker chromosomes in 27 patients by stepwise hybridization with alphasatellite DNA probes. Hum Genet. 1993;91:131-40.

30. Vorsanova SG, Yurov YB, Passarge I, Schmidt A, Zerova TE, Demidova IA, Buzhiyevskaya TI. Identification of marker chromosomes by in situ hybridization technique using alpha and "classical" satellite DNA probes with relative chromosomal specificity. Tsitol Genet. 1994;28(3):67-70.

31. Yurov YB, Vorsanova SG, Soloviev IV, Demidova IA, Alexandrov IA, Sharonin VO, Beresheva AK. Original collection of DNA probes for preimplantational, fetal prenatal and postnatal diagnosis of chromosomal analysis by FISH. In: Macek M, Bianchi D, Prague CH, editors. Early prenatal diagnosis, fetal cells and DNA in mother, present state and perspectives. 2002. p. 275-83.

32. Soloviev IV, Yurov YB, Vorsanova SG, Fayet F, Roizes G, Malet P. Prenatal diagnosis of trisomy 21 using interphase fluorescence in situ hybridization of post-replicated cells with site-specific cosmid and cosmid contig probes. Prenat Diagn. 1995;15:237-48.

33. Yurov YB, Soloviev IV, Vorsanova SG, Marcais B, Roizes G, Lewis R. High resolution multicolor fluorescence in situ hybridization using cyanine and fluorescein dyes: rapid chromosome identification by directly fluorescently labeled alphoid DNA probes. Hum Genet. 1996:97:390-8.

34. Yurov YB, Saias MJ, Vorsanova SG, Erny R, Soloviev IV, Sharonin VO, Guichaoua MR, Luciani JM. Rapid chromosomal analysis of germ-line cells by FISH: an investigation of an infertile male with large-headed spermatozoa. Mol Hum Reprod. 1996:2:665-8.

35. Vorsanova SG, Vekhova IV, Demidova IA, lurov IB. Mental retardation syndrome due to fragile $X$ chromosome: diagnostic and genetic problems. Zh Nevrol Psikhiatr Im S S Korsakova. 1998;98(9):54-63. 
36. lurov II, Vorsanova SG, lurov IB. Nervous and mental diseases in boys and mutations in MECP2 gene. Zh Nevrol Psikhiatr Im S S Korsakova. 2004;104(10):73-80.

37. Iurov II, Willard L, Vorsanova SG, Demidova IA, Goiko EA, Shal'nova SA, Shkol'nikova MA, Olfer'ev AM, lurov IB. X chromosome inactivation pattern in elderly women over 70 years of age. Tsitol Genet. 2004;38(4):49-54

38. Vorsanova SG, Ulas VI, Demidova IA, Kravets VS, lurov IB. Contemporary views on Rett's syndrome: clinical, cytogenetic and molecular studies. Zh Nevrol Psikhiatr Im S S Korsakova. 1999;99(3):61-9.

39. Vorsanova SG, lourov IY, Yurov YB. Neurological, genetic and epigenetic features of Rett syndrome. J Pediatr Neurol. 2004;2:179-90.

40. Vorsanova SG, Demidova IA, Ulas VY, Soloviev IV, Kazantzeva LZ, Yurov YB. Cytogenetic and molecular-cytogenetic investigation of Rett syndrome: analysis of 31 cases. Neuroreport. 1996;8:187-9.

41. Vorsanova SG, Demidova IA, Ulas VI, Solov'ev IV, Kravets VS, Kazantseva LZ, Iurov IB. Cytogenetic and molecular genetic diagnostics of Rett syndrome in children. Zh Nevrol Psikhiatr Im S S Korsakova. 1998;98(4):53-6.

42. Vorsanova SG, Yurov YB, Ulas WY, Demidova IA, Sharonin VO, Kolotii AD, Gorbatchevskaia NL, Beresheva AK, Soloviev IV. Cytogenetic and molecularcytogenetic studies of Rett syndrome (RTT): a retrospective analysis of a Russian cohort of RTT patients (the investigation of 57 girls and three boys). Brain Dev. 2001;23(1):S196-201.

43. Vorsanova SG, Ulas VI, lurov IB, Giovanucci-Uzielli ML, Demidova IA, Gianti L, Villard L, lurov II, Beresheva AK, Novikov PV. Genotype-phenotype correlations in Rett syndrome: the study of Russian cohort of patients. Zh Nevrol Psikhiatr Im S S Korsakova. 2002;102(10):23-9.

44. Vorsanova SG, Yurov YB, Kolotii AD, Soloviev IV. FISH analysis of replication and transcription of chromosome $X$ loci: new approach for genetic analysis of Rett syndrome. Brain Dev. 2001;23(1):S191-5.

45. Yurov YB, Vorsanova SG, Kolotii AD, lourov IY. Molecular-cytogenetic investigation of skewed chromosome $\mathrm{X}$ inactivation in Rett syndrome. Brain Dev. 2001;23(1):S214-7.

46. Iurov II, Vorsanova SG, Voinova-Ulas VI, Villard L, Demidova IA, Giunti L, Guivabyccu-Uzielli ML, Budilov AV, Beresheva AK, Novikov PV, lurov IV. Epigenetic study of Rett's syndrome as an adequate model for autistic disorders. Zh Nevrol Psikhiatr Im S S Korsakova. 2005;105(7):4-11.

47. Vorsanova SG, lurov II, Voinova VI, Kurinnaia OS, Zelenova MA, Demidova IA, Ulas EV, lurov IB. Subchromosomal microdeletion identified by molecular karyotyping using DNA microarrays (array CGH) in Rett syndrome girls negative for MECP2 gene mutations. Zh Nevrol Psikhiatr Im S S Korsakova. 2013;113(10):63-8

48. Iourov IY, Vorsanova SG, Voinova WY, Kurinnaia OS, Zelenova MA, Demidova IA, Yurov YB. Xq28 (MECP2) microdeletions are common in mutationnegative females with Rett syndrome and cause mild subtypes of the disease. Mol Cytogenet. 2013;6:53.

49. Vorsanova SG, lurov IB. Molecular cytogenetic pre- and postnatal diagnosis of chromosomal abnormalities. Vestn Ross Akad Med Nauk. 1999;11:12-5.

50. Vorsanova SG, Iurov IB, Solov'ev IV, Demidova IA, Sharonin VO, Male R, Zhiollant M, Beresheva AK, Kolotiĭ AD, Kravets VS, Ruazes Z. Current methods of molecular cytogenetics in pre- and postnatal diagnosis of chromosome aberrations. Klin Lab Diagn. 2000;8:36-9.

51. Iurov IB, Vorsanova SG. Molecular cytogenetic studies of chromosomal abnormalities and disorders in nervous and mental diseases: search for biological markers for diagnosis. Vestn Ross Akad Med Nauk. 2001;7:26-31.

52. lourov IY, Vorsanova SG, Yurov YB. Recent patents on molecular cytogenetics. Recent Pat DNA Gene Seq. 2008;2:6-15.

53. Vorsanova SG, Yurov YB, Kolotii AD, Demidova IA, Novikova IM. 16q subtelomeric deletion in proband with congenital malformations and mental retardation. Tsitol Genet. 2000;34(6):72-4.

54. Vorsanova SG, lourov IY, Demidova IA, Kolotii AD, Soloviev IV, Yurov YB. Pericentric inversion inv(7)(p11q21.1): report on two cases and genotypephenotype correlations. Tsitol Genet. 2006;40(3):45-8.

55. Vorsanova SG, lourov IY, Voinova-Ulas W, Weise A, Monakhov W, Kolotii AD, Soloviev IV, Novikov PV, Yurov YB, Liehr T. Partial monosomy 7q34-qter and 21 pter-q22.13 due to cryptic unbalanced translocation $\mathrm{t}(7 ; 21)$ but not monosomy of the whole chromosome 21: a case report plus review of the literature. Mol Cytogenet. 2008;1:13

56. Vorsanova SG, Kolotii AD, lourov IY, Monakhov W, Kirillova EA, Soloviev IV, Yurov YB. Evidence for high frequency of chromosomal mosaicism in spontaneous abortions revealed by interphase FISH analysis. J Histochem Cytochem. 2005;53:375-80.
57. Vorsanova SG, Kolotii AD, lurov II, Kirillova EA, Monakhov W, Beresheva AK, Solov'ev IV, lurov IB. Diagnosis of numerical chromosomal aberrations in the cells of spontaneous abortions by multicolor fluorescence in situ hybridization (MFISH). Klin Lab Diagn. 2005;11:30-2.

58. Vorsanova SG, lourov IY, Demidova IA, Kirillova EA, Soloviev IV, Yurov YB. Chimerism and multiple numerical chromosome imbalances in a spontaneously aborted fetus. Tsitol Genet. 2006;40(5):28-30.

59. Vorsanova SG, Yurov YB, lourov IY. Maternal smoking as a cause of mosaic aneuploidy in spontaneous abortions. Med Hypotheses. 2008;71(4):607.

60. Vorsanova SG, lurov II, Kolotii AD, Beresheva AK, Demidova IA, Kurinnaia OS, Kravets VS, Monakhov W, Solov'ev IV, lurov IB. Chromosomal mosaicism in spontaneous abortions: analysis of 650 cases. Genetika. 2010;46(10):1356-9.

61. Iourov IY, Vorsanova SG, Soloviev IV, Yurov YB. Interphase FISH: detection of intercellular genomic variations and somatic chromosomal mosaicism. In: Liehr T, editor. Fluorescence In Situ Hybridization (FISH) — Application Guide (Springer Protocols). Berlin, Heidelberg: Springer-Verlag; 2009. p. 301-11.

62. Yurov YB, Vorsanova SG, lourov IY. In: Yurov YB, Vorsanova SG, lourov IY, editors. Introduction to interphase molecular cytogenetics. in: Human Interphase Chromosomes (Biomedical Aspects). New York, Heidelberg, Dordrecht, London: Springer; 2013. p. 1-8.

63. Vorsanova SG, Yurov YB, lourov IY. Technological solutions in human interphase cytogenetics. in: Human Interphase Chromosomes (Biomedical Aspects). In: Yurov YB, Vorsanova SG, lourov IY, editors. . New York, Heidelberg, Dordrecht, London: Springer; 2013. p. 179-203.

64. Iourov IY, Vorsanova SG, Yurov YB. Detection of Nuclear DNA by Interphase Fluorescence In Situ Hybridization. In Encyclopedia of Analytical Chemistry, R. A. Meyers (Ed.). 2016. https://doi.org/10.1002/9780470027318.a9474.

65. Iourov IY, Vorsanova SG, Yurov YB. Interphase FISH for detection of chromosomal mosaicism. In: Liehr T, editor. Fluorescence In Situ Hybridization (FISH) - Application Guide (Springer Protocols Handbooks). Second ed. Berlin, Heidelberg: Springer-Verlag; 2017. p. 361-72.

66. Iourov IY, Vorsanova SG, Yurov YB. Intercellular genomic (chromosomal) variations resulting in somatic mosaicism: mechanisms and consequences. Curr Genomics. 2006;7:435-46.

67. Lourov IY, Vorsanova SG, Yurov YB. Somatic Genome Variations. In eLS, (Ed.). 2012. https://doi.org/10.1002/9780470015902.a0023889.

68. Jourov IY, Vorsanova SG, Yurov YB. Chromosomal variation in mammalian neuronal cells: known facts and attractive hypotheses. Int Rev Cytol. 2006:249:143-91.

69. Iurov IB, Khazatskii IA, Akindinov VA, Dovgilov LV, Kobrinskii BA, Vorsanova SG. Development of an original computer program FISHMet: use for molecular cytogenetic diagnosis and genome mapping by fluorescent in situ hybridization (FISH). Klin Lab Diagn. 2000;8:34-6.

70. Iourov IY, Soloviev IV, Vorsanova SG, Monakhov W, Yurov YB. An approach for quantitative assessment of fluorescence in situ hybridization (FISH) signals for applied human molecular cytogenetics. J Histochem Cytochem. 2005;53:401-8.

71. Iurov II, Solov'ev IV, Monakhov W, Vorsanova SG, lurov IB. Quantitative analysis of fluorescence in situ hybridization (FISH) signals for molecular cytogenetic diagnosis. Klin Lab Diagn. 2005;11:33-6.

72. Vorsanova SG, lourov IY, Beresheva AK, Demidova IA, Monakhov W, Kravets VS, Bartseva OB, Goyko EA, Soloviev IV, Yurov YB. Non-disjunction of chromosome 21, alphoid DNA variation, and sociogenetic features of Down syndrome. Tsitol Genet. 2005;39(6):30-6.

73. Iurov II, Vorsanova SG, Solov'ev IV, lurov IB. Original molecular cytogenetic approach to determining spontaneous chromosomal mutations in the interphase cells to evaluate the mutagenic activity of environmental factors. Gig Sanit. 2011;5:90-4.

74. Iourov IY, Vorsanova SG, Yurov YB. Fluorescence intensity profiles of in situ hybridization signals depict genome architecture within human interphase nuclei. Tsitol Genet. 2008;42(5):3-8.

75. Lourov IY, Liehr T, Vorsanova SG, Kolotii AD, Yurov YB. Visualization of interphase chromosomes in postmitotic cells of the human brain by multicolour banding (MCB). Chromosome Res. 2006;14:223-9.

76. Iourov IY, Liehr T, Vorsanova SG, Yurov YB. Interphase chromosome-specific multicolor banding (ICS-MCB): a new tool for analysis of interphase chromosomes in their integrity. Biomol Eng. 2007;24:415-7.

77. lurov II, Vorsanova SG, Solov'ev IV, Iurov IB. Molecular cytogenetic methods for studying interphase chromosomes in human brain cells. Genetika. 2010;46(9):1171-4 
78. lourov IY, Liehr T, Vorsanova SG, Yurov YB. Interphase chromosome-specific multicolor banding. In: Yurov YB, Vorsanova SG, lourov IY, editors. Human Interphase Chromosomes (Biomedical Aspects). New York, Heidelberg, Dordrecht, London: Springer; 2013. p. 161-9.

79. lourov IY, Vorsanova SG, Pellestor F, Yurov YB. Brain tissue preparations for chromosomal PRINS labeling. Methods Mol Biol. 2006;334:123-32.

80. Yurov YB, Vorsanova SG, Soloviev IV, Ratnikov AM, lourov IY. FISH-based assays for detecting genomic (chromosomal) mosaicism in human brain cells. Neuromethods. 2017;131:27-41.

81. Vorsanova SG, Yurov YB, lourov IY. Human interphase chromosomes: a review of available molecular cytogenetic technologies. Mol Cytogenet. 2010;3:1.

82. Yurov YB, Vorsanova SG, lourov IY. Human Interphase Chromosomes: Biomedical Aspects. New York: Springer; 2013

83. Yurov YB, Vostrikov VS, Monakhov W, lourov IY, Vorsanova SG. Evidence for large scale chromosomal variations in neuronal cells of the fetal human brain. Balkan J Med Genet. 2003;6:95-9.

84. Yurov YB, lourov IY, Monakhov W, Soloviev IV, Vostrikov VM, Vorsanova SG. The variation of aneuploidy frequency in the developing and adult human brain revealed by an interphase FISH study. J Histochem Cytochem. 2005;53:385-90.

85. Yurov YB, Vorsanova SG, Vostrikov VM, Monakhov W, Soloviev IV, lourov IY. In vitro cultivation of fetal brain cells induces aneuploidy: a caution for neural stem cell therapy? Int J Neuroprotec Neuroregener. 2006;2:209-11.

86. Yurov YB, lourov IY, Vorsanova SG, Liehr T, Kolotii AD, Kutsev SI, Pellestor F, Beresheva AK, Demidova IA, Kravets VS, Monakhov W, Soloviev IV. Aneuploidy and confined chromosomal mosaicism in the developing human brain. PLoS One. 2007;2:e558.

87. Lourov IY, Vorsanova SG, Liehr T, Yurov YB. Aneuploidy in the normal, Alzheimer's disease and ataxia-telangiectasia brain: differential expression and pathological meaning. Neurobiol Dis. 2009;34:212-20.

88. Iurov IB, Vorsanova SG, Solov'ev IV, lurov II. Instability of chromosomes in human nerve cells (normal and with neuromental diseases). Genetika. 2010;46(10):1352-5.

89. Yurov YB, Vostrikov VM, Vorsanova SG, Monakhov W, lourov IY. Multicolor fluorescent in situ hybridization on post-mortem brain in schizophrenia as an approach for identification of low-level chromosomal aneuploidy in neuropsychiatric diseases. Brain Dev. 2001;23(1):S186-90.

90. Iurov II, Vorsanova SG, lurov IB. Chromosome abnormalities in schizophrenia. Zh Nevrol Psikhiatr Im S S Korsakova. 2006;106(3):75-82.

91. lourov IY, Vorsanova SG, Yurov YB. Molecular neurocytogenetics demonstrates oncogenic parallels in schizophrenia: implications for neuroprotection and neuroregeneration. Int J Neuroprotec Neuroregener. 2006;2:212-4.

92. Yurov YB, lourov IY, Vorsanova SG, Demidova IA, Kravetz VS, Beresheva AK, Kolotii AD, Monakchov W, Uranova NA, Vostrikov VM, Soloviev IV, Liehr T. The schizophrenia brain exhibits low-level aneuploidy involving chromosome 1. Schizophr Res. 2008;98:139-47.

93. Yurov YB, Vorsanova SG, Demidova IA, Kravets VS, Vostrikov VM, Soloviev IV, Uranova NA, lourov IY. Genomic instability in the brain: chromosomal mosaicism in schizophrenia. Zh Nevrol Psikhiatr Im S S Korsakova. 2016;116(11):86-91.

94. Yurov YB, Vorsanova SG, Demidova IA, Kolotii AD, Soloviev IV, lourov IY. Mosaic brain aneuploidy in mental illnesses: an association of low-level post-zygotic aneuploidy with schizophrenia and comorbid psychiatric disorders. Curr Genomics. 2018;19:163-72.

95. Lourov IY Vorsanova SG, Yurov YB. Genomic landscape of the Alzheimer's disease brain: chromosome instability — aneuploidy, but not tetraploidy —mediates neurodegeneration. Neurodegener Dis. 2011;8:35-7.

96. Potter H, Granic A, lourov I, Migliore L, Vorsanova S, Yurov Y. Alzheimer's insight. The New Scientist. 2011;211(2824):32.

97. Yurov $\mathrm{YB}$, Vorsanova SG, lourov IY. The DNA replication stress hypothesis of Alzheimer's disease. ScientificWorldJournal. 2011;11:2602-12.

98. Yurov YB, Vorsanova SG, Liehr T, Kolotii AD, lourov IY. X chromosome aneuploidy in the Alzheimer's disease brain. Mol Cytogenet. 2014;7:20.

99. Iourov IY, Vorsanova SG, Yurov YB. Ataxia telangiectasia paradox can be explained by chromosome instability at the subtissue level. Med Hypotheses. 2007:68:716.

100. lourov IY, Vorsanova SG, Liehr T, Kolotii AD, Yurov YB. Increased chromosome instability dramatically disrupts neural genome integrity and mediates cerebellar degeneration in the ataxia-telangiectasia brain. Hum Mol Genet. 2009:18:2656-69.

101. Yurov YB, lourov IY, Vorsanova SG. Neurodegeneration mediated by chromosome instability suggests changes in strategy for therapy development in ataxia-telangiectasia. Med Hypotheses. 2009;73:1075-6.
102. Yurov YB, Vorsanova SG, lourov IY, Demidova IA, Beresheva AK, Kravetz VS, Monakhov W, Kolotii AD, Voinova-Ulas VY, Gorbachevskaya NL. Unexplained autism is frequently associated with low-level mosaic aneuploidy. J Med Genet. 2007:44:521-5.

103. Vorsanova SG, lurov II, Demidova IA, Voinova-Ulas VI, Kravets VS, Solov'ev IV, Gorbachevskaia NL, lurov IB. Variations of heterochromatic chromosomal regions and chromosome abnormalities in children with autism: identification of genetic markers in autistic spectrum disorders. Zh Nevrol Psikhiatr Im S S Korsakova. 2006;106(6):52-7.

104. Vorsanova SG, Yurov IY, Demidova IA, Voinova-Ulas VY, Kravets VS, Solov'ev IV, Gorbachevskaya NL, Yurov YB. Variability in the heterochromatin regions of the chromosomes and chromosomal anomalies in children with autism: identification of genetic markers of autistic spectrum disorders. Neurosci Behav Physiol. 2007;37:553-8.

105. lourov IY, Yurov YB, Vorsanova SG. Mosaic X chromosome aneuploidy can help to explain the male-to-female ratio in autism. Med Hypotheses. 2008;70:456.

106. Vorsanova SG, Voinova VI, lurov II, Kurinnaia OS, Demidova IA, lurov IB. Cytogenetic, molecular cytogenetic, clinical and genealogical study of mothers of children with autism: a search for family genetic markers of autistic disorders. Zh Nevrol Psikhiatr Im S S Korsakova. 2009;109(6):54-64.

107. Vorsanova SG, Voinova VY, Yurov IY, Kurinnaya OS, Demidova IA, Yurov YB. Cytogenetic, molecular-cytogenetic, and clinical-genealogical studies of the mothers of children with autism: a search for familial genetic markers for autistic disorders. Neurosci Behav Physiol. 2010;40:745-56.

108. lourov IY, Vorsanova SG, Yurov YB. Chromosomal mosaicism goes global. Mol Cytogenet. 2008;1:26.

109. Iourov IY, Vorsanova SG, Liehr T, Monakhov W, Soloviev IV, Yurov YB. Dynamic mosaicism manifesting as loss, gain and rearrangement of an isodicentric $Y$ chromosome in a male child with growth retardation and abnormal external genitalia. Cytogenet Genome Res. 2008;121:302-6.

110. lourov IY, Vorsanova SG, Yurov YB. Developmental neural chromosome instability as a possible cause of childhood brain cancers. Med Hypotheses. 2009;72:615-6.

111. Yurov YB, Vorsanova SG, lourov IY. GIN'n'CIN hypothesis of brain aging: deciphering the role of somatic genetic instabilities and neural aneuploidy during ontogeny. Mol Cytogenet. 2009;2:23.

112. lourov IY, Vorsanova SG, Yurov YB. Molecular cytogenetics and cytogenomics of brain diseases. Curr Genomics. 2008;9:452-65.

113. Yurov YB, lourov IY. Somatic genome variations: first steps towards a deeper understanding of an underappreciated source of biodiversity and disease. Curr Genomics. 2010;11:377-8.

114. Iourov IY, Vorsanova SG, Yurov YB. Somatic genome variations in health and disease. Curr Genomics. 2010;11:387-96.

115. Yurov YB, Vorsanova SG, lourov IY. Ontogenetic variation of the human genome. Curr Genomics. 2010;11:420-5.

116. Vorsanova SG, Yurov YB, Soloviev IV, lourov IY. Molecular cytogenetic diagnosis and somatic genome variations. Curr Genomics. 2010;11:440-6.

117. Tiganov AS, lurov IB, Vorsanova SG, lurov II. Genomic instability in the brain: etiology, pathogenesis and new biological markers of psychiatric disorders. Vestn Ross Akad Med Nauk. 2012;9:45-53.

118. Hultén MA, Jonasson J, Iwarsson E, Uppal P, Vorsanova SG, Yurov YB, lourov IY. Trisomy 21 mosaicism: we may all have a touch of Down syndrome. Cytogenet Genome Res. 2013;139:189-92.

119. Iourov IY, Vorsanova SG, Yurov YB. Interphase chromosomes of the human brain: the biological and clinical meaning of neural aneuploidy. in: Human Interphase Chromosomes (Biomedical Aspects). In: Yurov YB, Vorsanova SG, lourov IY, editors. . New York, Heidelberg, Dordrecht, London: Springer; 2013. p. 53-83.

120. Iourov IY, Vorsanova SG, Liehr T, Yurov YB. Mosaike im Gehirn des Menschen. Diagnostische Relevanz in der Zukunft? Medizinische Genetik. 2014:26:342-5.

121. lourov IY, Vorsanova SG, Yurov YB. Somatic cell genomics of brain disorders: a new opportunity to clarify genetic-environmental interactions. Cytogenet Genome Res. 2013;139:181-8.

122. lourov IY, Vorsanova SG, Yurov YB. Single cell genomics of the brain: focus on neuronal diversity and neuropsychiatric diseases. Curr Genomics. 2012;13:477-88.

123. Iurov II, Vorsanova SG, Saprina EA, Iurov IB. Identification of candidate genes of autism on the basis of molecular cytogenetic and in silico studies of the genome organization of chromosomal regions involved in unbalanced rearrangements. Genetika. 2010;46(10):1348-51. 
124. Iourov IY, Vorsanova SG, Yurov YB. In silico molecular cytogenetics: a bioinformatic approach to prioritization of candidate genes and copy number variations for basic and clinical genome research. Mol Cytogenet. 2014;7:98.

125. Yurov YB, Vorsanova SG, lourov IY. Network-based classification of molecular cytogenetic data. Curr Bioinform. 2017;12:27-33.

126. Vorsanova SG, Yurov YB, lourov IY. Neurogenomic pathway of autism spectrum disorders: linking germline and somatic mutations to geneticenvironmental interactions. Curr Bioinform. 2017;12:19-26.

127. Iourov IY, Vorsanova SG, Demidova IA, Aliamovskaia GA, Keshishian ES, Yurov YB. 5p13.3p13.2 duplication associated with developmental delay, congenital malformations and chromosome instability manifested as lowlevel aneuploidy. Springerplus. 2015;4:616.

128. lourov IY, Vorsanova SG, Zelenova MA, Korostelev SA, Yurov YB. Genomic copy number variation affecting genes involved in the cell cycle pathway: implications for somatic mosaicism. Int J Genomics. 2015;2015:757680

129. lourov IY, Vorsanova SG, Voinova VY, Yurov YB. 3p22.1 p21.31 microdeletion identifies CCK as Asperger syndrome candidate gene and shows the way for therapeutic strategies in chromosome imbalances. Mol Cytogenet. 2015;8:82.

130. lourov I, Vorsanova S, Yurov Y. Systems biology analysis and literature data mining for unmasking pathogenic neurogenomic variations in clinical molecular diagnosis. In Proceedings of the 11th International Joint Conference on Biomedical Engineering Systems and Technologies - Volume 4: Bioinformatics. 2018;160-165.

131. Iourov IY, Vorsanova SG, Kurinnaia OS, Zelenova MA, Silvanovich AP, Yurov YB. Molecular karyotyping by array CGH in a Russian cohort of children with intellectual disability, autism, epilepsy and congenital anomalies. Mol Cytogenet. 2012;5:46

132. Vorsanova SG, Iurov II, Kurinnaia OS, Voinova VI, lurov IB. Genomic abnormalities in children with mental retardation and autism: the use of comparative genomic hybridization in situ (HRCGH) and molecular karyotyping with DNA-microchips (array CGH). Zh Nevrol Psikhiatr Im S S Korsakova. 2013;113(8):46-9.

133. Iourov IY, Vorsanova SG, Kurinnaya OS, Kolotii AD, Demidova IA, Kravets VS, Yurov YB. The use of molecular cytogenetic and cytogenetic techniques for the diagnosis of Prader-Willi and Angelman syndrome. Zh Nevrol Psikhiatr Im S S Korsakova. 2014;114(1):49-53

134. lourov IY, Vorsanova SG, Korostelev SA, Zelenova MA, Yurov YB. Long contiguous stretches of homozygosity spanning shortly the imprinted loci are associated with intellectual disability, autism and/or epilepsy. Mol Cytogenet. 2015;8:77

135. lourov IY, Vorsanova SG, Korostelev SA, Vasin KS, Zelenova MA, Kurinnaia OS, Yurov YB. Structural variations of the genome in autistic spectrum disorders with intellectual disability. Zh Nevrol Psikhiatr Im S S Korsakova. 2016;116(7):50-4.

136. Vorsanova SG, Yurov YB, Chernyshov VN. Chromosomal syndromes and anomalies: classification and nomenclature. Rostov-on-Don: Rostov State Medical University; 1999

137. Yurov IY, Vorsanova SG, Yurov YB. Modern progress in the molecular cytogenetic diagnosis of hereditary diseases (a lecture). Klin Lab Diagn. 2005;11:21-9.

138. Vorsanova SG, Yurov YB, Chernyshov VN. Medical cytogenetics. Medpraktika: Moscow; 2006

139. Vorsanova SG, lourov IY, Soloviev IV, Yurov YB. Heterochromatic regions of human chromosomes: medical and biological aspects. Moscow: Medpraktika; 2008.

140. Iourov IY, Vorsanova SG, Yurov YB. Genomic and chromosomal disorders of the central nervous system. In: Molecular and cytogenetic aspects. Moscow: Medpraktika Moscow; 2014

141. Vorsanova SG, lourov IY, Demidova IA, Kravetz VS, Yurov YB. Cytogenetics and molecular cytogenetics of autism. Moscow: The publishing house of The Russian Academy of Natural History; 2016.

142. Vorsanova SG, lourov IY, Kurinnaia OS, Yurov YB. Idiopathic intellectual disability in children: cytogenetic and molecular cytogenetic aspects. Moscow: The publishing house of The Russian Academy of Natural History; 2017.

143. Yurov YB, lourov IY. Molecular Cyto(post)genomics. Current Genomics. 2018;19:157.

144. Iourov IY, Zelenova MA, Voinova WY, Yurov YB. 4q21.2q21.3 duplication: molecular and neuropsychological aspects. Curr Genomics. 2018;19:173-8.

145. Vorsanova SG, Zelenova MA, Yurov YB, lourov IY. Behavioral variability and somatic mosaicism: a cytogenomic hypothesis. Curr Genomics. 2018;19:158-62.
146. Yurov YB, Liehr T, Shaffer LG, lourov IY, Vorsanova SG. A new open access journal for a rapidly evolving biomedical field: introducing Molecular Cytogenetics. Mol Cytogenet. 2008;1:1.

147. Liehr T, Heng H, Yurov Y, Meloni-Ehrig A, lourov I. Molecular Cytogenetics: the first impact factor (2.36). Mol Cytogenet. 2013;6:28.

\section{Ready to submit your research? Choose BMC and benefit from:}

- fast, convenient online submission

- thorough peer review by experienced researchers in your field

- rapid publication on acceptance

- support for research data, including large and complex data types

- gold Open Access which fosters wider collaboration and increased citations

- maximum visibility for your research: over $100 \mathrm{M}$ website views per year

At BMC, research is always in progress.

Learn more biomedcentral.com/submissions 